\title{
Perbedaan Pengasuhan Anak di Sekolah Fullday dan Sekolah Umum Terhadap Kemandirian Anak
}

\author{
Niken Purnamasari ${ }^{\bowtie}$, Dimyati $^{2}$ \\ Pendidikan Anak Usia Dini, Universitas Negeri Yogyakarta, Indonesia(1) \\ Pendidikan Ilmu Keolahragaan, Universitas Negeri Yogyakarta, Indonesia(2) \\ DOI: $\underline{10.31004 / o b s e s i . v 6 i 4.2267}$
}

\begin{abstract}
Abstrak
Tujuan penelitian untuk mengetahui dan menganalisis perbedaan kemandirian anak TK antara sekolah fullday dan umum; dan rata-rata tingkat kemandirian anak TK sekolah fullday dibanding dengan sekolah umum. Jenis penelitian adalah penelitian kuantitatif dengan pendekatan komparatif. Tempat penelitian di TKIT MTA Polanharjo (fullday) dan TK Pertiwi Sidoharjo Polanharjo Klaten (umum). Waktu penelitian dilakukan bulan April-Mei 2021. Teknik pengambilan sampel menggunakan total sampling, yaitu semua siswa diambil sebagai sampel penelitian: TKIT MTA (56 siswa) dan TK Pertiwi Sidoharjo (20 siswa). Teknik pengumpulan data menggunakan lembar observasi yang diisi oleh guru. Teknik analisis data menggunakan analisis deskriptif dan Kruskal-Wallis Test. Hasil penelitian menyimpulkan bahwa terdapat perbedaan kemandirian anak TK antara program fullday dan umum. Skor rata-rata tingkat kemandirian anak TK sekolah fullday $(17,86)$ lebih tinggi dibandingkan sekolah umum $(16,55)$. Temuan ini mengindikasikan bahwa pendidikan usia dini yang diberikan secara intensif dapat membentuk kepribadian anak, seperti meningkatkan kemandirian anak.
\end{abstract}

Kata kunci: kemandirian anak; sekolah fullday; sekolah umum

\begin{abstract}
The aims of the study were to identify and analyze the differences in the independence of kindergarten children between full-day and general schools; and the average level of independence of full-day kindergarten children compared to general schools. This type of research is quantitative research with a comparative approach. The research sites are TKIT MTA Polanharjo (full day) and TK Pertiwi Sidoharjo Polanharjo Klaten (general). The time of the study was carried out in April-May 2021. The sampling technique used total sampling, namely all students were taken as research samples: TKIT MTA (56 students) and TK Pertiwi Sidoharjo (20 students). The data collection technique used an observation sheet filled out by the teacher. The data analysis technique used descriptive analysis and the Kruskal-Wallis test. The results of the study concluded that there were differences in the independence of kindergarten children between full day and general programs, the average score of the independence level of full-day kindergarten children (17.86) is higher than that of public schools (16.55). These findings indicate that intensive early childhood education can shape children's personalities, such as increasing children's independence
\end{abstract}

Keywords: Child independence; full day school; general school

Copyright (c) 2022 Niken Purnamasari, Dimyati

$\triangle$ Corresponding author:

Email Address : nikenpurnamasari9@gmail.com (Yogyakarta, Indonesia)

Received 10 October 2021, Accepted 28 January 2022, Published 4 Febaruay 2022 


\section{PENDAHULUAN}

Anak usia dini yang berusia 4-6 tahun, memiliki karakteristik antara lain: (1) Berkaitan dengan perkembangan fisik, anak sangat aktif melakukan berbagai kegiatan. Hal itu bermanfaat untuk pengembangan otot-otot kecil maupun besar; (2) Perkembangan bahasa juga semakin baik. Anak sudah mampu memahami pembicaraan orang lain dan mampu mengungkapkan pikiran nya dalam batas-batas tertentu; (3) Perkembangan kognitif (daya pikir) sangat pesat, ditunjukkan dengan rasa ingin tahu anak yang luar biasa terhadap lingkungan sekitar. Hal itu terlihat dari seiring nya anak menanyakan segala sesuatu yang dilihat; (4) Bentuk permainan anak masih bersifat individu, bukan permainan sosial. Walaupun aktivitas bermain dilakukan secara bersama (Susanto, 2018).

Anak usia dini yang berumur 4-6 tahun umumnya memasuki masa sekolah di TK/RA. Menurut Piaget dalam Yusuf (2019), perkembangan kognitif anak pada usia taman kanakkanak berada pada periode praoperasional, anak belum mampu menguasai operasi mental secara logis. Periode ini ditandai dengan perkembangannya representasioanl atau symbolic function, yaitu kemampuan untuk menggunakan simbol untuk mewakili sesuatu yang lain dengan menggunakan kata-kata, bahasa gerak, gesture, dan benda. Melalui kemampuan ini anak mampu berimajinasi atau berfantasi mengenai berbagai hal.

Anak usia dini didefinisikan oleh National Association for the Education of Young Children (NAEYC) (1992) yaitu asosiasi para pendidik anak yang berpusat di Amerika, sebagai rentang usia anak usia dini berdasarkan perkembangan hasil penelitian di bidang psikologi perkembangan anak yang mengindikasikan bahwa terdapat pola umum yang dapat diprediksi menyangkut perkembangan yang terjadi selama 8 tahun pertama kehidupan anak. NAEYC membagi anak usia dini menjadi 0-3 tahun, 3-5 tahun, dan 6-8 tahun. Menurut definisi ini anak usia dini merupakan kelompok manusia yang berada pada proses pertumbuhan dan perkembangan. Hal ini mengisyaratkan bahwa anak usia dini adalah individu yang unik yang memiliki pola pertumbuhan dan perkembangan fisik, kognitif, sosio-emosional, kreativitas, bahasa dan komunikasi yang khusus sesuai dengan tahapan yang sedang dilalui oleh anak tersebut (Purnama \& Hidayati, 2020).

Pendidikan anak usia dini (PAUD) berdasarkan Permendikbud Nomor 146 tahun 2014 Pasal 1 Kurikulum 2013 dijelaskan bahwa " Pendidikan anak usia dini merupakan jenjang pendidikan sebelum jenjang pendidikan dasar sebagai suatu upaya pembinaan yang ditunjukan bagi anak sejak lahir sampai dengan usia enam tahun. Dilakukan melalui pemberian rangsangan pendidikan untuk membantu pertumbuhan dan perkembangan jasmani serta rohani agar anak memiliki kesiapan dalam memasuki pendidikan lebih lanjut".

Agar anak usia dini memiliki kesiapan memasuki pendidikan lebih lanjut, maka anak harus memiliki kemandirian. Susanto (2018) menjelaskan bahwa kemandirian (autonomi) harus mulai diperkenalkan kepada anak sedini mungkin. Dengan menanamkan kemandirian akan menghindarkan anak dari sifat ketergantungan pada orang lain, dan yang terpenting dalam menumbuhkan keberanian anak dilakukan dengan memberikan motivasi pada anak untuk terus mengetahui pengetahuan-pengetahuan baru memulai pengawasan orang tua.

Berdasarkan pengamatan yang dilakukan di TK, ditemukan pada saat kedatangan murid diantar sampai ke dalam kelas, masih ada anak yang belum mampu membuka/memakai sepatu sendiri, ketika berbaris masih ada yang belum mampu mengikuti aturan dalam berbaris. Pada saat pembelajaran di sekolah, anak-anak tersebut masih didampingi oleh guru. Saat beraktivitas di dalam kelas, kebanyakan anak-anak tampak sibuk bermain dengan teman di sebelahnya, dengan demikian saat guru menerangkan di dalam kelas anak-anak tidak dapat menangkap instruksinya dengan baik dan akhirnya pekerjaan yang diberikan oleh guru tidak dapat dikerjakan oleh anak. Selain itu, saat anak-anak makan bersama, terlihat beberapa anak masih meminta bantuan guru untuk membuka pembungkus makanannya. Pada waktu istirahat, beberapa anak khusunya di TK A tidak mau bermain, cenderung menyendiri atau hanya sebagai penonton saja dan terkesan takut dan malu untuk 
berinteraksi dengan temannya. Fenomena tersebut menunjukkan rendahnya kemandirian anak.

Rendahnya kemandirian pada anak usia dini merupakan kendala bagi anak untuk mengikuti pendidikan yang lebih tinggi. Oleh sebab itu, pentingnya ditanamkan kemandirian pada anak sejak dini karena dengan melatih anak mandiri, anak tidak akan mudah bergantung pada orang lain dan dapat tumbuh menjadi anak yang memiliki jiwa yang kuat serta membentuk kepribadian yang unggul. Dengan ditanamkannya kemandirian sejak dini, maka ketika dewasa anak akan lebih mudah dalam mengambil keputusan, bertanggung jawab, tidak mudah bergantung pada orang lain, dan mampu menyesuaikan diri dengan lingkungannya (Sa'diyah, 2017).

Suwarsiyah mengungkapkan bahwa anak yang tidak mandiri dipengaruhi oleh sikap khawatir berlebihan dari orang tua. Sikap terlalu khawatir orang tua mengakibatkan anak menjadi ketergantungan dengan bantuan orang tua dan menjadikan anak kurang mandiri. Anak yang kurang mandiri tidak berani melakukan sesuatu dengan maksimal atau tingkat kepercayaan diri rendah. Anak yang tidak mandiri menjadi kurang berinisiatif dalam melakukan kegiatannya dan cenderung untuk bergantung pada orang lain. Oleh karenanya orang tua tidak harus selalu membantu pada setiap kegiatan yang dilakukan anak (Suwarsiyah, 1999). Oleh karena itu orang tua dan guru sebaiknya menstimulasi kemandirian anak sejak usia dini. Rantina menambahkan bahwa faktor penyebab dari permasalahan rendahnya kemandirian anak dalam proses pembelajaran diantaranya adalah guru dalam menggunakan metode pembelajaran masih klasikal, dan menggunakan metode ceramah serta metode penugasan, sedangkan anak membutuhkan kebebasan dalam memilih kegiatan apa yang disenanginya sehingga ia menjadi anak yang mandiri dan tidak tergantung pada orang lain (Rantina, 2015).

Kemandirian penting bagi anak, karena kemandirian merupakan ciri dari pribadi yang sehat. Hal ini seperti yang dijelaksan oleh Yusuf (2019) bahwa kemandirian merupakan karakteristik dari kepribadian yang sehat (healthy personality). Kemandirian individu tercermin dari cara berpikir dan bertindak, mampu mengambil keputusan, mengarahkan dan mengembangkan diri, serta menyesuaikan diri secara konstruktif dengan norma yang berlaku di lingkungannya.

Northrup dalam Susanto (2018) menambahkan bahwa ada delapan unsur yang menyertai makna kemandirian bagi seorang anak, yaitu: (1) Kemampuan untuk menentukan pilihan, (2) Berani memutuskan atas pilihannya sendiri, (3) Bertanggung jawab menerima konsekuensi yang menyertai pilihannya; (4) Percaya diri; (5) Mengarahkan diri; (6) Mengembangkan diri; (7) Menyesuaikan diri dengan lingkungan, dan; (8) Berani mengambil risiko atas pilihannya.

Nelliraharti \& Sari mengungkapkan bahwa banyak orang tua yang kurang peduli apa yang terjadi dengan anak dan dipelajari anak di sekolah. Mereka merasa sudah membayar mahal biaya sekolah, sehingga mereka merasa tidak perlu lagi mendidik anak di rumah. Padahal keluarga adalah organisasi yang sangat penting dalam penciptaan pendidikan dan perkembangan awal seorang anak (Ekawati \& Iriani, 2020). Saat pandemi Covid-19, orang tua memiliki peran sebagai pembelajar anak, pemenuh kebutuhan anak, pemahaman spiritual, pengawasan, motivasi, dan penyedia fasilitas anak. Pendampingan belajar anak terlihat dari cara orang tua membantu kesulitan tugas anak, menjelaskan materi yang tidak dimengerti anak, dan merespon dengan baik semua pembelajaran daring dari sekolah (Yulianingsih et al., 2020).

Beberapa upaya untuk mendorong tumbuhnya kemandirian anak sejak dini ini menyarankan agar orang tua, guru dan lingkungan sekitarnya perlu memberikan gambaran yang bisa membentuk perilaku mandiri anak dengan konsep Developmentally Appropriate Practice (DAP) adalah metode pembelajaran yang menyenangkan bagi anak dan selain itu sesuai dengan perkembangan anak (Karmila et al., 2020). Salah satu pembelajaran untuk mengembangkan keterampilan sikap mandiri anak dengan aktivitas yang sering anak 
lakukan secara langsung adalah kegiatan rutin di rumah. Perkembangan kemandirian yang terjadi pada anak usia dini pada usia 5-6 tahun ini, kemampuannya sudah sampai pada tahap mampu mengerjakan tugas yang menjadi tanggung jawabnya sendiri seperti membersihkan, dan membereskan tempat bermain, menaati aturan kelas, mampu mengatur diri sendiri, dan bertanggung jawab atas perilakunya Kemandirian Anak Usia Dini di Masa Pandemi Covid19 untuk kebaikan diri sendiri (Yusutria \& Febriana, 2019).

Contoh lain seperti buang air kecil (BAK) dan buang air besar (BAB) pembiasaan pada aktivitas ini juga harus di latih dalam menggunakan toilet. Latihan penggunaan toilet adalah sebuah usaha pembiasaan mengontrol BAB dan BAK secara benar dan teratur (Pramono \& Risnawati, 2018). Montessori yang menjelaskan bahwa, mengajarkan nilai-nilai kemandirian pada anak dapat melalui kegiatan praktis sehari-hari agar anak memperoleh kebebasan untuk melakukan hal yang mereka butuhkan (Wulandari \& Purwanta, 2020). Mereka dapat melakukan hal yang mereka butuhkan untuk bertahan hidup seperti menyiapkan makan, memasang kancing, mengikat tali sepatu, mencuci tangan, dan lain-lain (Danauwiyah \& Dimyati, 2021)

Anak yang mandiri adalah anak yang memiliki kepercayaan diri dan motivasi yang tinggi sehingga dalam setiap tingkah lakunya tidak banyak menggantungkan diri dengan orang lain, biasanya pada orang tuanya. Anak yang kurang mandiri selalu ingin ditemani atau ditunggu oleh orang tuanya baik pada saat sekolah maupun pada saat bermain, kemana-mana harus ditemani orang tua atau saudaranya. Berbeda dengan anak yang memiliki kemandirian, yang berani memutuskan pilihannya sendiri tingkat kepercayaan dirinya lebih tampak, serta mudah menyesuaikan diri dengan lingkungan dan teman bermain maupun orang asing yang baru dikenalnya.

Anak yang mandiri adalah anak yang memiliki kepercayaan diri dan motivasi yang tinggi sehingga dalam setiap tingkah lakunya tidak banyak menggantungkan diri dengan orang lain, biasanya pada orang tuanya. Anak yang kurang mandiri selalu ingin ditemani atau ditunggu oleh orang tuanya baik pada saat sekolah maupun pada saat bermain, kemana-mana harus ditemani orang tua atau saudaranya. Berbeda dengan anak yang memiliki kemandirian, yang berani memutuskan pilihannya sendiri tingkat kepercayaan dirinya lebih tampak, serta mudah menyesuaikan diri dengan lingkungan dan teman bermain maupun orang asing yang baru dikenalnya.

Kemandirian anak sangat berkaitan erat dengan pola asuh orang tua di lingkungan keluarga (Lestari, 2019). Setiap orang tua memiliki pola asuh yang berbeda mulai dari demokratis, authoritative, authoritarian sampai permisif. Lestari (2019) mengatakan bahwa pola asuh authoritative dan demokratif memiliki dampak yang lebih signifikan daripada pola asuh authoritarian. Maka penting bagi orang tua untuk memperhatikan pola asuhnya karena pola asuh yang tepat dapat menumbuhkan kemandirian anak.

Selain pola asuh, lingkungan sekolah juga bisa mendorong terbentuknya kemandirian anak. Sekolah juga perlu berkontribusi dan berkomitmen memupuk nilai-nilai kemandirian yang sudah diajarkan melalui pola asuh yang diadopsi oleh orang tua. Pembelajaran sekolah dapat meningkatkan kemandirain anak (Khotijah, 2018).

Hasil penelitian Purnama \& Hidayati (2020) menemukan bahwa indikator-indikator pengasuhan anak dapat direduksi dari data inti aspek-aspek pengasuhan yaitu asuh, asih, dan asah. Hasil penelitian Ulfah (2020) menyimpulkan bahwa Dukungan keluarga sebagai penyelenggaran pendidikan anak di rumah dan partisipasi aktif dalam kegiatan di sekolah menjadi faktor pendukung keberhasilan pendekatan holistik integratif pada PAUD full day.

Oleh karena itu, faktor lingkungan sekolah dapat mempengaruhi kemandirian anak, salah satunya adalah program fullday. Banyak orang tua yang lebih memilih menyekolahkan anak mereka di sekolah yang menyediakan program fullday. Alasan para orang tua menyekolahkan anak mereka di fullday school salah satunya karena fullday school memberikan kegiatan tambahan seperti kegiatan keagamaan dan kegiatan mengurus diri sendiri. Selain itu beberapa orang tua yang bekerja di luar rumah tidak ada waktu untuk mengurus anak mereka 
beralasan agar anak mereka bisa lebih mandiri saat ditinggal oleh orang tua. Istilah fullday School berarti siswa belajar di sekolah sehari penuh mulai pagi hingga sore hari. Jadi, waktu anak dihabiskan dengan kegiatan-kegiatan di sekolah. Akan tetapi bukan berarti anak melakukan kegiatan sehari penuh tanpa beristirahat, anak diberikan waktu tidur siang yaitu biasanya setelah melaksanakan solat dzuhur (Moh Agus Rohman, 2018). Program fullday sekolah dapat berpengaruh terhadap kemandirian anak. Hal ini sesuai hasil penelitian Dwiasmira (2012) yang menyimpulkan bahwa ada perbedaan kemandirian antara anak-anak yang mengikuti TK program fullday dengan anak-anak yang mengikuti TK program reguler (umum) dan anak-anak di TK fullday lebih mandiri dari anak-anak di TK reguler (umum).

\section{METODOLOGI}

Jenis penelitian adalah penelitian kuantitatif dengan pendekatan komparatif, dengan desain sebagaimana pada gambar 1 .

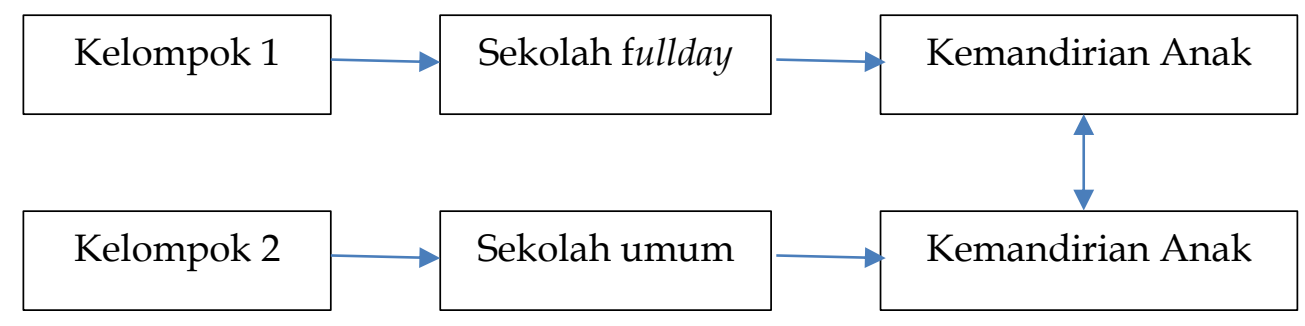

\section{Gambar 1 Desain Penelitian}

Tempat penelitian di TKIT MTA Polanharo Klaten (fullday) dan TK Pertiwi Sidoharjo Polaharjo Klaten (umum). Waktu penelitian dilakukan bulan April-Mei 2021. Teknik pengambilan sampel menggunakan total sampling, yaitu semua siswa yang ada di masingmasing TK diambil sebagai sampel penelitian, yaitu TKIT MTA Polanharjo berjumlah 56 siswa dan TK Pertiwi Sidoharjo berjumlah 20 siswa. Teknik pengumpulan data menggunakan lembar observasi yang diisi oleh guru. Teknik analisis data menggunakan analisis deskriptif, uji homogenitas data, dan uji t (apabila data terdistribusi normal) atau Kruskal-Wallis Test (apabila data tidak terdistribusi normal).

\section{HASIL DAN PEMBAHASAN}

\section{Analisis Deskriptif}

Aspek atau indikator yang digunkan untuk mengukur kemandirian anak terdiri atas tujuh indikator, yaitu: (1) memiliki kepercayaan kepada diri sendiri; (2) memiliki motivasi instrinsik yang tinggi; (3) mampu dan berani menentukan pilihannya sendiri; (4) kreatif dan inovatif; (5) bertanggung jawab menerima konsekuensi yang menyertai pilihannya; (6) mampu menyesuaikan diri dengan lingkungannya; (1) tidak bergantung pada orang lain (Susanto, 2018) Berdasarkan analisis deskriptif diperoleh tabel seperti disajikan pada tabel 1.

\begin{tabular}{lrrrrr}
\multicolumn{7}{c}{ Tabel 1 Hasil Analisis Deskriptif } \\
Descriptive Statistics \\
\\
\hline N & Min & Max & Mean & \multicolumn{1}{c}{ SD } \\
\hline MTA & 56 & 12,00 & 23,00 & 17,857 & 2,252 \\
PERTIWI & 20 & 14,00 & 21,00 & 16,550 & 2,115 \\
Valid N (listwise) & 20 & & & & \\
\hline
\end{tabular}

Pada tabel 1 terlihat bahwa rata-rata (mean) skor kemandirian pada siswa TKIT MTA Polaharjo adalah 17,857 $\pm 2,252$, sedangkan siswa TK Petiwi Sidoharjo adalah 16,550 $\pm 2,115$. Jadi rata-rata skor kemadirian anak TKIT MTA Polanharjo lebih tinggi dibanding dengan TK Pertiwi Sidoharjo. 


\section{Uji Homogenitas Data}

Berdasarkan uji homogenitas data menggunakan One-Way Anova diperolah hasil seperti disajikan pada pada tabel 2.

Tabel 2 Hasil Uji Homogenitas Data

Test of Homogeneity of Variances

Kemandirian

\begin{tabular}{r|r|r|r}
\hline Levene Statistic & \multicolumn{1}{c}{ df1 } & \multicolumn{1}{c}{ df2 } & \multicolumn{1}{c}{ Sig. } \\
\hline, 016 & 1 & 74 &, 898 \\
\hline
\end{tabular}

Pada tabel 2 terlihat bahwa nilai Levene Statistic adalah 0,016 dengan signifikansi 0,898 $>0,05$, artinya data kemandirian anak sekolah fullday dan sekolah umum memiliki varians yang sama (homogen).

\section{Uji Normalitas Data}

Berdasarkan uji normalitas data menggunakan Kolmogorov-Smirnov diperolah hasil seperti disajikan pada tabel 3.

\begin{tabular}{lrrr}
\multicolumn{3}{c}{ Tabel 3 Hasil Uji Normalitas Data } \\
One-Sample Kolmogorov-Smirnov Test \\
\hline \multicolumn{3}{c}{ MTA } & PERTIWI \\
\hline $\mathrm{N}$ & & 56 & 20 \\
Normal & Mean & 17,8571 & 16,5500 \\
Parametersa,b & Std. Deviation & 2,25169 & 2,11449 \\
Most Extreme & Absolute & 0,155 & 0,153 \\
Differences & Positive & 0,148 & 0,153 \\
& Negative & $-0,155$ & $-0,114$ \\
Test Statistic & 0,155 & 0,153 \\
Asymp. Sig. (2-tailed) & $0,002 \mathrm{c}$ \\
\hline a. Test distribution is Normal. & 0,200 c,d \\
b. Calculated from data. & \\
c. Lilliefors Significance Correction. & \\
d. This is a lower bound of the true significance. &
\end{tabular}

Pada tabel 3 terlihat bahwa data kemandirian pada siswa TKIT MTA Polanharjo tidak terdistribusi normal, karena nilai asyimp.sig sebesar 0,002 <0,05, dan data kemandiarian pada siswa TK Pertiwi Sidoharjo terdistribusi normal dengan nilai asyimp.sig sebesar 0,200>0,05. Mengingat ada salah satu kelompok data yang tidak terdistribusi normal, maka uji komparasi menggunakan Kruskal-Wallis Test.

\section{Perbedaan Kemandirian Anak TK}

Berdasarkan hasil Kruskal-Wallis Test diperoleh hasil seperti disajikan pada tabel 4 .

Tabel 4 Hasil Kruskal-Wallis Test

\begin{tabular}{llrr}
\multicolumn{2}{c}{ Ranks } & \\
\hline & KODE & N & Mean Rank \\
\hline KEMANDIRIAN & 1,00 & 56 & 41,96 \\
& 2,00 & 20 & 28,83 \\
& Total & 76 & \\
\hline
\end{tabular}




\begin{tabular}{lr}
\multicolumn{2}{c}{ Test Statistics a,b } \\
\hline \multicolumn{2}{c}{ KEMANDIRIAN } \\
\hline Chi-Square & 5,345 \\
df & 1 \\
Asymp. Sig. & 0,021 \\
\hline a. Kruskal Wallis Test & \\
b. Grouping Variable: KODE &
\end{tabular}

Pada tabel 4 terlihat bahwa mean rank untuk siswa TKIT MTA Polanharjo adalah 41,96 dan untuk siswa TK Pertiwi Sidoharjo adalah 28,83. Selajutnya nilai chi square sebesar 5,345 dengan signifikansi 0,021 <0,05. Berarti ada perbedaan signifikan antara kemandirian antara siswa TKIT MTA Polanharjo dengan TK Pertiwi Sidoharjo. Sesuai dengan hasil analisis deskriptif, maka rata-rata skor kemadirian anak TKIT MTA Polanharjo lebih tinggi dibanding dengan TK Pertiwi Sidoharjo. Hasil penelitian ini mendukung hasil penelitian (Yulistyas Dwiasmira, 2012) menyimpulkan bahwa ada perbedaan kemandirian antara anak-anak yang mengikuti TK program fullday dengan anak-anak yang mengikuti TK program reguler (umum) dan anak-anak di TK fullday lebih mandiri dari anak-anak di TK reguler (umum).

Hasil penelitian Nisa \& Sujarwo (2021) menunjukkan bahwa Semakin efektif komunikasi tutor (guru) kepada anak usia dini, semakin meningkat motivasi mereka untuk mengikuti semua proses pembelajaran. Hasil penelitian Pitaloka \& Purwanta (2021) menyimpulkan bawa peran guru dalam menanamkan nilai toleransi pada anak antara lain dengan merancang kurikulum toleransi, memiliki kompetensi yang optimal dan proporsional serta memiliki komitmen yang kuat dalam memberikan teladan kepada anak mengenai nilainilai karakter salah satunya nilai toleransi. Peran guru dalam menanamkan nilai toleransi juga dapat melalui kegiatan pembelajaran dengan menggunakan beberapa metode seperti memberikan keteladanan, pemberian arahan, pembiasaan, kegiatan mendongeng, kegiatan permainan, dan penggunaan media. Untuk itu, menurut Sudrajat sekolah harus membuat suatu strategi yang tepat guna proses pendidikan di lembaganya dapat berlangsung dengan baik dan tetap terjaga mutu kualitas pembelajaran yang diberikan oleh guru kepada anak didiknya (Warmansyah, 2020).

Banyak orang tua yang lebih memilih menyekolahkan anak mereka di sekolah yang menyediakan program fullday. Alasan para orang tua menyekolahkan anak mereka di fullday school salah satunya karena fullday school memberikan kegiatan tambahan seperti kegiatan keagamaan dan kegiatan mengurus diri sendiri. Selain itu beberapa orang tua yang bekerja di luar rumah tidak ada waktu untuk mengurus anak mereka beralasan agar anak mereka bisa lebih mandiri saat ditinggal oleh orang tua. Istilah fullday School berarti siswa belajar di sekolah sehari penuh mulai pagi hingga sore hari. Jadi, waktu anak dihabiskan dengan kegiatankegiatan di sekolah. Akan tetapi bukan berarti anak melakukan kegiatan sehari penuh tanpa beristirahat, anak diberikan waktu tidur siang yaitu biasanya setelah melaksanakan solat dzuhur (Moh Agus Rohman, 2018).

Menurut Wibowo, ruang lingkup kurikulum di Taman Kanak-kanak dan RA diarahkan pada aspek perkembangan anak usia dini diantaranya: 1) moral dan nilai-nilai agama, 2) sosial emosional dan kemandirian, 3) kemampuan berbahasa, 4) kognitif, 5) fisik dan motorik, 6) seni budaya (Iswantiningtyas \& Wulansari, 2019). Hasil penelitian (Nuraeni et al., 2019) menyimpulkan bahwa peningkatan karakter anak usia dini secara nyata dipengaruhi oleh adanya program Sekolah Ramah Anak.

Salah satu wujud sekolah ramah anak adalah tidak ada perilaku bullying. Hasil penelitian Mahriza et al. (2021) menunjukkan bahwa bentuk bullying yang dilakukan anak seperti; mengejek, mengolok-olok, memukul, mencubit, menendang, menginjak kaki, mendorong teman. Tindakan preventif guru bersifat tindakan rasionalitas instrumental, dengan bentuk melerai dan memisahkan anak yang sedang memukul/mengejek temannya, disertai dengan cara memisahkan tempat duduk antar siswa sehingga mereka tidak kembali 
ricuh. Tindakan bersifat rasional nilai, seperti guru menegur anak yang memukul, menendang, mengejek, mencubit, mendorong temannya. Kemudian guru menyuruh anak untuk meminta maaf kepada temannya. Selanjutnya tindakan bersifat tindakan afektif, di mana guru menghibur si anak saat temannya mendorong, mengejek, mencubit, mengolokolok anak tersebut.

Abu et al. menjelaskan guru dapat menginternalisasi pendidikan karakter dalam pendidikan agama melalui kegiatan beribadah dan menjalin hubungan sosial yang baik dengan sesama (Na'imah et al., 2020). Peran serta guru pada pengasuhan adalah dengan memberikan pendekatan dan edukasi terhadap pengasuh dan juga anak (Rahmaningrum \& Fauziah, 2020). Di sekolah, guru harus mampu untuk bekerja sama dengan para orang tua agar guru juga mengetahui permasalahan ibu dan anak, serta mengetahui perilaku anak di rumah (Nauli et al., 2019).

Murray \& Harrison menjelaskan bahwa anak menjadi „siap' dalam keberhasilan akademis awal ketika orang tua dan gurunya mendukung (Mardliyah et al., 2020). Pengembangan kemandirian anak menurut Suhada dapat dilakukan dengan cara: a) meningkatkan proses belajar mengajar yang absolut; b) mengajak anak ikut serta dalam menetukan keputusan; c) Memberikan keleluasaan pada anak dalam mengeksplorasi lingkungan; d) Penerimaan positif tidak membeda-bedakan anak yang satu dengan yang lainnya; dan e) mempererat hubungan yang harmonis dan akrab dengan anak (Damayanti, 2019).

Terdapat beberapa perbedaan sekolah fullday dan sekolah umum (reguler), diantaranya: 1) sekolah fullday lebih lama dibandingkan dengan sekolah reguler, yaitu pada umumnya sekolah dimulai pukul 07.30-10.30, sekolah fullday memulai kegiatannya dari pukul 07.30-15.00. 2) fullday school memiliki kegiatan yang lebih banyak dibandingkan regular school. 3) pada fullday school anak mendapat perhatian dan pengawasan penuh dari guru, sedangkan pada sekolah reguler jika sudah waktunya pulang sekolah anak kurang mendapat perhatian dan pengawasan dari orang tua karena orang tua yang sedang bekerja di luar rumah. Dengan demikian banyak orang tua yang tertarik untuk menyekolahkan anak mereka di sekolah yang memiliki program fullday.

Menurut Desmita (2015), menyatakan kemandirian adalah usaha untuk melepaskan diri dari orang tua dengan maksud untuk menemukan dirinya melalui proses mencari identitas ego, yaitu merupakan perkembangan ke arah individualitas yang mantap dan berdiri sendiri. Kemandirian biasanya ditandai dengan kemampuan menentukan nasib sendiri, kreatif, dan inisiatif, mengatur tingkah laku, bertanggung jawab, mampu menahan diri, membuat keputusan-keputusan sendiri, serta mampu mengatasi masalah tanpa ada pengaruh dari orang lain. Astiati dalam Wiyani (2017) menjelaskan bahwa kemandirian merupakan kemampuan atau keterampilan yang dimiliki anak untuk melakukan segala sesuatunya sendiri, baik yang terkait dnegan aktivitas bantu diri maupun aktivitas dalam kesehariannya tanpa tergantung pada orang lain.

Puryanti menjelaskan kemandirian dapat dikembangkan melalui berbagai latihanlatihan yang dilakukan secara bertahap. Latihan-latihan tersebut dapat dilakukan dengan memberikan pembiasaan untuk melakukan tugas sederhana sesuai dengan tahapan perkembangan anak dan mudah untuk dilakukan. Misalnya mandi sendiri, memakai baju sendiri, mengancingkan baju, menali sepatu, makan tidak disuapi, membereskan mainan setelah digunakan, pergi ke kamar mandi sendiri, dan kegiatan-kegiatan ringan yang dilakukan sehari-hari (Amin et al., 2020).

Menurut Zimmerman dalam Susanto (2018) bahwa anak yang mandiri itu adalah anak yang mempunyai kepercayaan diri dan motivasi intrinsik yang tinggi. Zimmerman yakin bahwa kepercayaan diri dan motivasi intrinsik tersebut merupakan kunci utama bagi kemandirian anak. Dengan kepercayaan dirinya, anak berani tampil dan berekspresi di depan orang banyak atau di depan umum. Penampilannya tidak terlihat malu-malu, kaku, atau canggung, tetapi ia mampu beraksi dengan wajar bahkan mengesankan. Sementara itu, 
motivasi intrinsik atau motivasi bawaan dapat membawa anak untuk berkembang lebih cepat, terutama perkembangan otak atau kognitifnya. Anak yang memiliki motivasi tinggi ini dapat terlihat dari perilakunya yang aktif, kreatif, dan memiliki sifat ingin tahu (curiositas) yang tinggi. Anak tersebut biasanya selalu banyak bertanya dan serba ingin tahu, selalu mencobanya, mempraktikannya, dan mencoba sesuatu yang baru.

Kemandirian berkaitan dengan kebebasan seorang individu untuk bertindak bebas sesuai keinginannya. Hal ini sesuai pendapat Masrun dalam Hasanah (2016) menyatakan bahwa kemandirian adalah suatu sifat yang memungkinkan seseorang bertindak bebas, melakukan sesuatu atas dorongan diri sendiri, mengejar prestasi, penuh keyakinan dan memiliki keinginan untuk mengerjakan sesuatu tanpa bantuan orang lain, mampu mengatasi persoalan yang dihadapi, mampu mengendalikan tindakan, mampu mempengaruhi lingkungan, mempunyai rasa percaya diri terhadap kemampuan yang dimiliki, menghargai keadaan diri dan memperoleh kepuasan atas usaha sendiri.

Menurut Susanto (2018) ciri atau indikator kemandirian anak termasuk juga pada anak usia dini yaitu; 1) Kepercayaan pada diri sendiri: Rasa percaya diri atau dalam kalangan anak muda biasa disebut dengan istilah 'PD' ini sengaja di tempatkan sebagai ciri pertama dari sifat kemandirian anak. Oleh karena itu , memang rasa percaya diri ini memegang peran penting bagi seseorang, termasuk anak usia dini, dalam bersikap dan bertingkah laku atau dalam beraktivtas sehari-hari. Anak yang memiliki kepercayaan diri lebih berani untuk melakukan sesuatu, menentukan pilihan sesuai dengan kehendaknya sendiri, dan bertanggung jawab terhadap konsekuensi yang ditimbulkan karena pilihannya. Kepercayaan diri sangat terkait dengan kemandirian anak. Dalam kasus tertentu, anak yang memiliki percaya diri yang tinggi dapat menutupi kekurangan dan kebodohan yang melekat pada dirinya. Untuk itu, dalam berbagai kesempatan sikap percaya diri perlu ditanamkan dan dipupuk sejak awal pada anak usia dini ini. 2) Motivasi intrinsik yang tinggi: Motivasi instrinsik adalah dorongan yang tumbuh dalam diri untuk melakukan sesuatu. Motivasi intrinsik biasanya lebih kuat dan abadi dibandingkan dengan motivasi ekstrinsik, walaupun kedua motivasi ini kadang berkurang, tetapi kadang juga bertambah. Kekuatan yang datang dari dalam akan mampu menggerakan untuk melakukan sesuatu yang diinginkan. Keingintahuan seseorang yang murni merupakan salah satu contoh motivasi intrinsik. Dengan adanya keingintahunya yang mendalam ini dapat mendorong seseorang untuk melakukan sesuatu yang memungkinkan ia memperoleh apa yang dicita-citakan. 3) Mampu dan berani menentukan pilihan sendiri: Anak mandiri memiliki kemampuan dan keberanian dalam menentukan pilihan sendiri. Misalnya, dalam memilih alat bermain atau alat belajar yang akan digunakannya. 4) Kreatif dan inovatif: Pada anak usia dini merupakan ciri anak yang memiliki kemandirian, seperti dalam melakukan sesuatu atas kehendak sendiri tanpa disuruh oleh orang lain, tidak ketergantungn kepada orang lain dalam melakukan sesuatu, menyukai pada hal-hal baru yang semula dia belum tahu dan selalu ingin menciba hal-hal yang baru. 5) Bertanggung jawab menerima konsekuensi yang menyertai pilihannya: Di dalam mengambil keputusan atau pilihan tentu ada konsekuensi yang melekat pada pilihannya. Anak yang mandiri akan bertanggung jawab atas keputusan yang diambilnya apa pun yang terjadi, tetapi tentu saja bagi anak taman kanak-kanak tanggung jawab pada taraf yang wajar. Misalnya, tidak menangis ketika ia salah mengambil alat mainan, dan senang hati mengganti dengan alat mainan yang lain yang diinginkan. 6) Menyesuaikan diri dengan lingkungannya: Lingkungan sekolah (Taman Kanak-kanak) merupakan lingkungan baru bagi anak-anak. Hal ini sering dijumpai anak menangis ketika pertama masuk sekolah karena mereka merasa asing dengan lingkungan di Taman Kanak-kanak bahkan tidak sedikit yang ingin ditunggui oleh orang tuanya ketika anak sedang belajar. Namun, bagi anak yang memiliki kemandirian, dia akan cepat menyesuaikan diri dengan lingkungan yang baru. 7) Tidak ketergantungan kepada orang lain: Anak mandiri selalu ingin mencoba sendiri dalam melakukan sesuatu, tidak bergantung pada orang lain dan anak tahu kapan waktunya meminta bantuan orang lain. Setelah anak berusaha melakukannya sendiri, tetapi tidak mampu untuk mendapatkannya, baru anak meminta 
bantuan orang lain. Misalnya, mengambil alat mainan yang berada di tempat yang tidak terjangkau oleh anak.

Berdasarkan uraian di atas, maka pendidikan usia dini yang diberikan secara intensif (seperti sekolah fullday) dapat membentuk kepribadian anak, seperti meningkatkan kemandirian anak. Hal ini karena TK fullday dimulai pukul 07.30 WIB hingga 15.00 WIB, memiliki kegiatan yang lebih banyak dibandingkan TK umum, serta anak mendapat perhatian dan pengawasan penuh dari guru. Pada TK fullday, anak umumnya tidak ditunggui oleh orang tuanya, dan anak banyak diajari oleh guru untuk dapat melakukan sendiri aktivitas sehari-hari seperti: makan dan minum sendiri, memakai sepatu sendiri, ke kamar mandi sendiri, mengerjakan tugas sekolah sendiri, dan kegiatan lain yang dapat membentuk anak menjadi pribadi yang mandiri.

\section{SIMPULAN}

Terdapat perbedaan kemandirian anak TK antara sekolah fullday dan umum yang ditunjukkan dengan nilai chi square sebesar 5,345 dengan signifikansi 0,021<0,05. Dibandingkan anak sekolah umum, anak sekolah fullday lebih menonjol dalam hal: mengerjakan sendiri tugas sekolah, merapikan sendiri mainan, tidak ditunggui orang tua saat sekolah, makan dan minum sendiri, serta memakai sepatu sendiri. Skor rata-rata tingkat kemandirian anak TK sekolah fullday $(17,86)$ lebih tinggi dibandingkan sekolah umum $(16,55)$. Temuan ini mengindikasikan bahwa pendidikan usia dini yang diberikan secara intensif dapat membentuk kepribadian anak, terutama aspek kemandirian

\section{UCAPAN TERIMA KASIH}

Peneliti mengucapkan terima kasih kepada kepala sekolah, guru dan orang tua anak yang telah berpartisipasi aktif membantu pengumpulan data penelitian.

\section{DAFTAR PUSTAKA}

Amin, M., Kristiana, D., \& Fadlillah, M. (2020). Pengaruh Kelekatan Aman Anak pada Ibu terhadap Kemandirian Anak Usia 5-6 Tahun. Jurnal Obsesi : Jurnal Pendidikan Anak Usia Dini, 5(1), 127. https://doi.org/10.31004/obsesi.v5i1.504

Damayanti, E. (2019). Meningkatkan Kemandirian Anak melalui Pembelajaran Metode Montessori. Jurnal Obsesi: Jurnal Pendidikan Anak Usia Dini, 4(1), 463. https:// doi.org/10.31004/obsesi.v4i1.333

Danauwiyah, N. M., \& Dimyati, D. (2021). Kemandirian Anak Usia Dini di Masa Pandemi Covid-19. Jurnal Obsesi: Jurnal Pendidikan Anak Usia Dini, 6(2), 588-600. https:// doi.org/10.31004/obsesi.v6i2.994

Desmita. (2012). Psikologi Perkembangan. Remaja Rosdakarya.

Ekawati, E. Y., \& Iriani, A. (2020). Evaluasi Discrepancy Program Parenting Class dalam Rangka Meningkatkan Hubungan Masyarakat. Jurnal Obsesi : Jurnal Pendidikan Anak Usia Dini, 5(1), 117. https:// doi.org/10.31004/obsesi.v5i1.525

Hasanah, U. (2016). Sikap Over Proteksi Orang Tua Dan Kematangan Sosial Anak. Journal AnNafs: Kajian Penelitian Psikologi, 1(1), 133-150. https:// doi.org/10.33367/psi.v1i1.248

Iswantiningtyas, V., \& Wulansari, W. (2019). Penanaman Pendidikan Karakter pada Model Pembelajaran BCCT (Beyond Centers and Circle Time). Jurnal Obsesi: Jurnal Pendidikan Anak Usia Dini, 3(1), 110. https:// doi.org/10.31004/obsesi.v3i1.106

Karmila, R., Khosiah, S., \& Fahmi, F. (2020). Pengaruh rutinitas di rumah terhadap kemandirian anak. Jurnal Pendidikan Luar Sekolah, 14(1), 20. https:// doi.org/10.32832/jpls.v14i1.3348

Khotijah, I. (2018). Peningkatan Kemandirian Anak Melalui Pembelajaran Practical Life. Jurnal Golden Age, 2(02), 127. https:// doi.org/10.29408/goldenage.v2i02.1100 
Lestari, D. P. (2019). Peningkatan Kreatifitas Melalui Funcooking pada Kelompok A RA Az Zahra Kebayoran Baru Jakarta Selatan. Jurnal PG-PAUD Trunojoyo: Jurnal Pendidikan Dan Pembelajaran Anak Usia Dini, 6(1), 18-28. https://doi.org/10.21107/pgpaudtrunojoyo.v6i1.5370

Mahriza, R., Rahmah, M., \& Santi, N. E. (2020). Stop Bullying: Analisis Kesadaran dan Tindakan Preventif Guru pada Anak Pra Sekolah. Jurnal Obsesi : Jurnal Pendidikan Anak Usia Dini, 5(1), 891-899. https:// doi.org/10.31004/obsesi.v5i1.739

Mardliyah, S., Siahaan, H., \& Budirahayu, T. (2020). Pengembangan Literasi Dini melalui Kerjasama Keluarga dan Sekolah di Taman Anak Sanggar Anak Alam Yogyakarta. Jurnal Obsesi: Jurnal Pendidikan Anak Usia Dini, 4(2), 892-899. https://doi.org/10.31004/obsesi.v4i2.476

Moh Agus Rohman. (2018). Kejenuhan Belajar Pada Siswa di Sekolah Dasar Full Day School. SKRIPSI, 9(1), 1-11. https:/ / doi.org/10.1016/j.gaitpost.2018.12.007

Na'imah, T., Widyasari, Y., \& Herdian, H. (2020). Implementasi Sekolah Ramah Anak untuk Membangun Nilai-Nilai Karakter Anak Usia Dini. Jurnal Obsesi : Jurnal Pendidikan Anak Usia Dini, 4(2), 747. https:// doi.org/10.31004/obsesi.v4i2.283

Nauli, V. A., Karnadi, K., \& Meilani, S. M. (2019). Peran Ibu Pedagang Pasar 24 Jam Terhadap Perkembangan Moral Anak (Penelitian Studi Kasus di Kota Bekasi). Jurnal Obsesi : Jurnal Pendidikan Anak Usia Dini, 3(1), 241. https:// doi.org/10.31004/obsesi.v3i1.179

Nisa, K., \& Sujarwo, S. (2020). Efektivitas Komunikasi Guru terhadap Motivasi Belajar Anak Usia Dini. Jurnal Obsesi: Jurnal Pendidikan Anak Usia Dini, 5(1), 229. https://doi.org/10.31004/obsesi.v5i1.534

Novan Ardy Wiyani. (2014). Bina Karakter Anak Usia Dini.

Nuraeni, L., Andrisyah, A., \& Nurunnisa, R. (2019). Efektivitas Program Sekolah Ramah Anak dalam Meningkatkan Karakter Anak Usia Dini. Jurnal Obsesi : Jurnal Pendidikan Anak Usia Dini, 4(1), 20. https:// doi.org/10.31004/obsesi.v4i1.204

Pitaloka, D. L., Dimyati, D., \& Purwanta, E. (2021). Peran Guru dalam Menanamkan Nilai Toleransi pada Anak Usia Dini di Indonesia. Jurnal Obsesi : Jurnal Pendidikan Anak Usia Dini, 5(2), 1696-1705. https:// doi.org/10.31004/obsesi.v5i2.972

Pramono, D., \& Risnawati, A. (2018). Meningkatkan Kedisiplinan Anak Usia Dini Melalui Latihan Pembiasaan Penggunaan Toilet di KB Al-Hidayah Insan Mandiri Kabupaten Bandung. Jurnal Obsesi: Jurnal Pendidikan Anak Usia Dini, 2(1), 61. https://doi.org/10.31004/obsesi.v2i1.8

Purnama, S., \& Hidayati, L. (2020). Pengasuhan Anak Usia Dini dalam Hikayat Indraputra. Jurnal Obsesi: Jurnal Pendidikan Anak Usia Dini, 4(2), 520. https://doi.org/10.31004/obsesi.v4i2.391

Rahmaningrum, A., \& Fauziah, P. (2020). Peran Guru pada Pengasuhan Anak dari Keluarga Tenaga Kerja Indonesia. Jurnal Obsesi : Jurnal Pendidikan Anak Usia Dini, 5(2), 12821292. https:// doi.org/10.31004/obsesi.v5i2.796

Rantina, M. (2015). Peningkatan Kemandirian Melalui Kegiatan Pembelajaran Practical Life (Penelitian Tindakan Di TK B Negeri Pembina Kabupaten Lima Puluh Kota,Tahun 2015). Pendidikan Usia Dini, 9(2), 181-200. https://media.neliti.com/media/publications/118232-ID-peningkatan-kemandirianmelalui-kegiatan.pdf

Sa'diyah, R. (2017). Pentingnya Melatih Kemandirian Anak. Kordinat: Jurnal Komunikasi Antar Perguruan Tinggi Agama Islam, 16(1), 31-46. https://doi.org/10.15408/kordinat.v16i1.6453

Susanto, A. (2018). Pendidikan Anak Usia Dini. Bumi aksara.

Suwarsiyah, A. (1999). Menumbuhkan Kemandirian Anak, Kreativitas Dan Konsep Diri Yang Sehat Anak Usia Dini; Sebuah Tinjauan. UII. 
Ulfah, M. (2019). Pendekatan Holistik Integratif Berbasis Penguatan Keluarga pada Pendidikan Anak Usia Dini Full Day. Jurnal Obsesi : Jurnal Pendidikan Anak Usia Dini, 4(1), 10. https://doi.org/10.31004/obsesi.v4i1.255

Warmansyah, J. (2020). Program Intervensi Kembali Bersekolah Anak Usia Dini Masa Pandemi Covid-19. Jurnal Obsesi: Jurnal Pendidikan Anak Usia Dini, 5(1), 743. https://doi.org/10.31004/obsesi.v5i1.573

Wulandari, H., \& Purwanta, E. (2020). Pencapaian Perkembangan Anak Usia Dini di Taman Kanak-kanak selama Pembelajaran Daring di Masa Pandemi Covid-19. Jurnal Obsesi : Jurnal Pendidikan Anak Usia Dini, 5(1), 452. https:// doi.org/10.31004/obsesi.v5i1.626

Yulianingsih, W., Suhanadji, S., Nugroho, R., \& Mustakim, M. (2020). Keterlibatan Orangtua dalam Pendampingan Belajar Anak selama Masa Pandemi Covid-19. Jurnal Obsesi : Jurnal Pendidikan Anak Usia Dini, 5(2), 1138-1150. https:// doi.org/10.31004/obsesi.v5i2.740

Yulistyas Dwiasmira. (2012). Studi Komparasi Kemandirian Anak Taman Kanak-Kanak (TK) Di Program Fullday Dan Reguler [Universitas Muhammadiyah Surakarta]. In Universitas Muhammadiyah Surakarta. http://eprints.ums.ac.id/19924/25/11._Naskah_Publikasi.pdf

Yusuf, S. (2019). Psikologi Perkembangan Anak \& Remaja (R. Rosdakarya (ed.)).

Yusutria, Y., \& Febriana, R. (2019). Aktualisasi Nilai-Nilai Kemandirian Dalam Membentuk Karakter Mandiri Siswa. Ta'dib: Jurnal Pendidikan Islam, 8(1), 577-582. https:// doi.org/10.29313/tjpi.v8i1.4575 